1 Berry CL. Solitary "necrotic nodule" of the liver; a probable pathogenesis. J Clin Pathol 1985;38:1278-80.

2 Berry CL. Solitary necrotic nodule of liver; a non-existent lesion. J Pathol 1985; 146:263A.

3 Shepherd NA, Lee G. Solitary necrotic nodules of the liver simulating hepatic metastases. Clin Pathol 1983;36:1181-3.

4 Berry CL. Liver lesions in an autopsy population. Hum Toxicol 1987;6:209-14.

\section{Prevalence of HTLV-I in Zimbabwe}

The letter by Emmanuel $e t$ al is of tantalising interest but requires definitive confirmation. ${ }^{1}$ Seroprevalence studies for HTLV-I have been conducted in different parts of the world including the Caribbean, ${ }^{23}$ Papua New Guinea, ${ }^{4}$ and West Africa. ${ }^{5}$ An extensive survey from Southern Africa would have enlightened us further as to the global distribution of this pathogen. Dr Emmanuel found four (out of 900) samples to be reactive by ELISA (Dupont), "in patients sent for HIV exclusion". Samples from only two patients were also positive by Serodia-ATLA test. While the Serodia-HIV assay is used as a confirmatory anti-HIV test, the Serodia antiATLV or HTLV-I (-II) assay is indeed a sensitive screen test but is of low specificity, even without regard to the problems of some cross-reaction between HIV and HTLV-I ${ }^{6}$ or interference of ELISA reactivity from malaria and immune complexes. ${ }^{78}$

In 1988, at the North London Blood Transfusion Centre, we screened over 6000 individual samples using the Serodia-ATLA kit. Out of 4136 routine blood donors, 49 ( 1 in 80 ) were screen test positive when tested in accordance with the manufacturer's criteria. Even higher Serodia-ATLA screen test positive rates of 1 in 50 (51:2376) were found in samples collected for malaria antibody testing - that is, donations from people who come from or have travelled to areas endemic for malaria or tropical areas. All but one, however, were reported as HTLV-I negative by the Virology Reference Laboratory at The Middlesex Hospital, London, indicating the high incidence of false positive results with this test at the recommended screening dilutions.

When reference laboratories are readily available, the indirect immunofluorescence assay may be used for confirmation. ${ }^{9}$ We recognise that confirmation of HTLV-I seropositivity is, at present, still a problem. Obviously PCR and RIPA would be outside the range of many laboratories, especially in developing countries, but we would like to reinforce the following point: as is the case with anti-HIV testing, samples reacting by ELISA or by particle agglutination screening tests, especially in relation to anti-HTLV, require extensive confirmatory testing. In the absence of such testing, the clinical importance of four samples reactive by ELISA in Zimbabwe remains unclear.

$$
\begin{array}{r}
\text { J RUNGANGA, } \\
\text { JAJ BARBARA, } \\
\text { M CONTRERAS, } \\
\text { North London Blood Transfusion Centre, } \\
\text { Colindale Avenue, } \\
\text { London NW9 } 5 B G
\end{array}
$$

1 Emmanuel JC, Bassett MT, Smith HJ, Patterson L. Prevalence of HTLV-I in Zimbabwe: pilot survey. $J$ Clin Pathol 1989;42:670-1.

2 Gessain A, Barin F, Fernant JC, et al. Antibodies to human T-lymphotropic virus Antibodies to human T-lymphotropic virus
type-I in patients with tropical spastic type-1 in patients with tropical
paraparesis. Lancet 1985:ii:407-10.
3 Bartholomew C, Saxinger WC, Clark JW, et al Transmission of HTLV-I and HIV among homosexual men in Trinidad JAMA 1987; 257:2604-8.

4 Babona DV, Nurse GT. HTLV-I antibodies in Papua New Guinea. Lancet 1988;ii: 1148. and tropical spastic paraparesis in Africa. Lancet 1986;ii:698. MA, Sarngadharan MG, Gallo RC. Serologic analysis of a subgroup of human T-lymphotropic retroviruses (HTLV-III) associated with AIDS. Science 1984;224: 503-5.

7 Biggar RJ, Gigase PL, Melbye M, et al. ELISA associated with malaria and immune complexes in healthy Africans. Lancet 1985; ii: 250-3.

8 McLaughlin GL, Benedik MJ, Campbell GH. Repeated immunogenic amino acid sequences of Plasmodium species share sequence homologies with proteins from humans and human viruses. Am J Trop Med Hyg 1987; 37:258-62.

9 Hinuma Y, Nagata K, Hanaoka $M$, et al. Adult T cell leukemia: antigen in ATL cell line and detection of antibodies to the antigen in human sera. Proc Natl Acad Sci USA 78: 6476-80.

\section{Arteritis of the tongue}

We were interested to read the letter by Misselevitch et al on giant cell arteritis of the tongue associated with squamous cell carcinoma.' The factors they enumerate for elastic lamina injury are also important in the establishment of fungal infection in the mouth. ${ }^{2}$ We have observed several cases of fungal arteritis of the head and neck in patients with cancer; such an arteritis can look deceptively like giant cell arteritis, especially if special stains for fungi are not used. The illustration shows an example of a Mucor arteritis of the head and neck in a patient with bilateral
5 Gessain A, Francis H, Sonan T, et al. HTLV-I

6 Schupbach J, Popovic M, Gilden RV, Gonda HTLV retrovirus antibody reactivity

breast carcinomas and concurrent chronic lymphocytic leukaemia.

D J WILLIAMS, $S$ LANE

Department of Pathology, The University of Leeds,
Leeds LS2 $9 \mathrm{JT}$

1 Misselevitch I, Fradis M, Podoshin L, Barel E, Boss JH. Giant cell arteritis of the tongue associated with squamous cell carcinoma. Clin Pathol 1989;42:1001-5.

2 Macfarlane TW, Samaranayake LP. Clinical oral microbiology. London: Butterworth 1989: 122-39.

Dr Boss et al comment

The comments on our observation of giant cell arteritis of the tongue associated with squamous cell carcinoma are relevant at a time when fungal diseases in the immune compromised cancer patient are being recognised more frequently. Moreover, for as yet unknown reasons, fungi have a special affinity for blood vessels and we have previously encountered double fungal infestation of the pulmonary circulation. ' The bizarrely distorted elastic lamellae of the arteries are a characteristic feature of, among others, mycotic vasculitis. In our laboratory it is routine custom to request special stains for acid fast bacteria and fungi whenever giant cell granulomatous lesions are found, whether affecting a vessel or otherwise. In the patient we described no micro-organisms were detected in the affected branch of the lingual artery.

1 Stermer E, Bassan H, Oliven A, Grishkan A, Boss $\mathrm{JH}$. Massive thrombosis as a result of
triple infestation of the pulmonary arterial triple infestation of the pulmonary arterial
circulation by ascaris, candida and mucor. circulation by ascaris, candidat
Hum Pathol 1984;15:996-8.

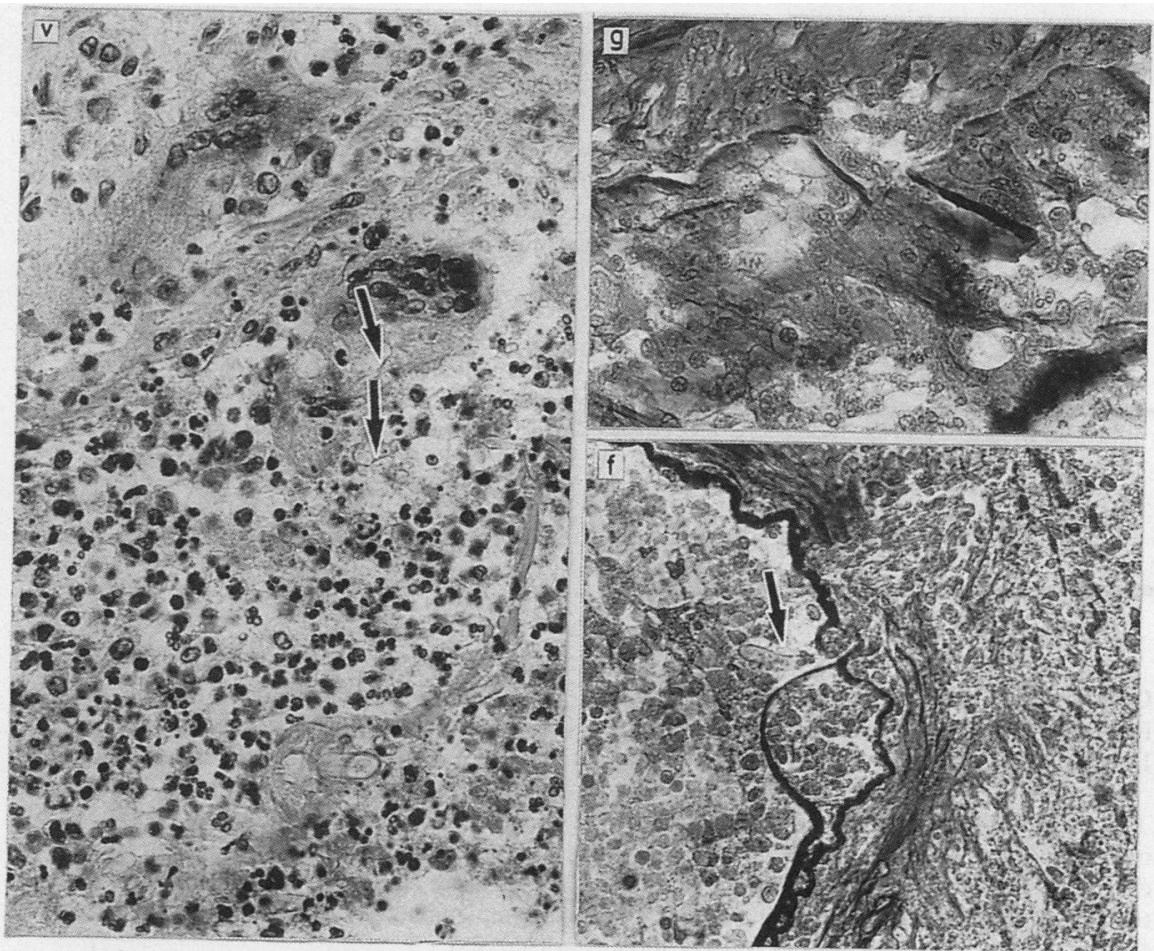

(v) Mucor (arrows) and giant cells in inflamed vessel wall (Haematoxylin and eosin.)

(g) Elastica fragments in the giant cells (Elastica van Gieson.)

(f) Mucor hypha (arrow) emerging from a break in the elastica (Elastica van Gieson.) 